\title{
Factors Influencing the Acceptance of International Public Sector Accounting Standards in Cameroon
}

\author{
Mukah Samuel Tanjeh ${ }^{1}$ (Ph.D.) \\ ${ }^{1}$ Accounting Programme, Department of Economics and Management, Faculty Of Social And Management Sciences, \\ University Of Buea, Cameroon \\ Correspondence: Mukah Samuel Tanjeh, (Ph.D.), Accounting Programme, Department of Economics and \\ Management, Faculty Of Social And Management Sciences, University Of Buea, Cameroon
}

Received: March 7, 2016

Accepted: April 1, 2016

Online Published: April 18, 2016

doi:10.5430/afr.v5n2p71

URL: http://dx.doi.org/10.5430/afr.v5n2p71

\begin{abstract}
There is a growing consensus that governments should be held financially accountable, and Cameroon like many developing countries faces the challenge of running a sound government accounting system that guarantees accountability and transparency. Governments strive to adopt a new public management philosophy which focuses on the change in management practices of the public sector towards more private sector practices with the aim of rendering the public sector more cost effective and efficient. The transition from cash to accrual based International Public Sector Accounting Standards (IPSAS) in order to overcome the rising unaccountability and opaqueness in the use of public sector finances becomes a daunting task. In this respect, Cameroon tends to accept international accounting standards that can be adapted easily to its local situation and also make its financial reports more reliable, standardised, comparable, and attractive on the international scene. With this backdrop, the paper sought to investigate the factors influencing the acceptance of government accounting reforms in general and IPSAS in particular in Cameroon. A survey was conducted in the Ministry of Finance (MINFI) and the Ordinary Least Squares (OLS) and Ordered Logistics Estimation techniques used. The main findings revealed the determining factors of IPSAS acceptance in Cameroon namely: knowledge and awareness, institutional organisation, staff training and recruitment, management information system, qualification, sex, implementation cost, political support, and age. The paper ends up proposing a careful study of these factors by the government for any successful public sector accounting reform and IPSAS acceptance to take place.
\end{abstract}

Keywords: Government accounting reform, Public financial management, IPSAS, Contingency model

\section{Introduction}

The global anxiety for better public financial management that guarantees more accountability and transparency is the concern of both developed and developing countries. In view of this, the International Federation of Accountants (IFAC) establishes and promotes the application of International Public Sector Accounting Standards (IPSAS) by public sector entities around the world when preparing their General Purpose Financial Reports (GPFR).

The main aim of IPSAS is to improve the quality of GPFR by public sector entities so as to have a better informed assessment of the decisions governments take to allocate resources. Compliance with IPSAS guarantees that financial reporting by public entities conveys a "true and fair view" of the financial situation. The adoption of IPSAS therefore, enhances transparency and accountability by governments in the management of public resources. It raises the quality of financial management, facilitates transactions with financiers and simplifies communication with the general public. IPSAS assure comparability of financial reporting with other countries, motivation of foreign investors to make investment in the country, and very helpful in raising capital from the international markets (International Public Sector Accounting Standards Board, 2013; South Asian Federation of Accountants, 2006).

Consequently, public sector accounting carries out a basic purpose of safeguarding the public treasury by timely preventing and detecting corruption (Chan, 2003). This basic purpose of government accounting meets enormous challenges. According to the report of the High Level Panel on Illicit Financial Flows from Africa commissioned by the African Union (AU) and United Nations Economic Commission for Africa (UNECA) Conference of Ministers of Finance, Planning and Economic Development, over the period 1970 and 2008 Africa lost about $\$ 850$ billion. Nigeria 
lost about $\$ 217.7$ billion, Egypt $\$ 105.2$ billion and South Africa more than $\$ 81.8$ billion in illicit financial outflows (African Union and United Nations economic commission for Africa, 2015).

The public sector accounting and financial system in Cameroon is managed by the Ministry of Finance (MINFI) which ensures the preparation, approval and implementation of the government budgets, and the preparation of the public sector financial reports for audit and publication. In the last two decades the system faced serious challenges of timely detecting and preventing financial irregularities and losses. No public sector audit has so far disclosed a mega financial scandal masterminded and executed in the year preceding the audit. Rather, financial indecorums are uncovered several years after the crime has been committed (Mukah, 2015).

Fundamental to the development of an efficient public sector accounting and reporting system in any country is the ability to identify and measure the government's expenses, revenues, assets and liabilities properly. Where this is not possible or is roughly done as it is the case with the Cameroon public sector which still largely focuses on administrative and management accounts and the adoption of CEMAC regulations in 2013, corruption steps in to understate the government's revenue and assets or to overstate government's expenses and liabilities. However, Cameroon strives to gain the confidence of investors and donors as she brawls with government accounting reforms. According to Ehsan, et al., 2012, financial integrity assurance and accurate accrual accounting is an accountant's professional contribution to its country.

Logically, any official acceptance of a public sector accounting reform in general and of IPSAS in particular in Cameroon should be preceded by an identification and assessment of the determining factors of the acceptance. Many accounting and financial reforms delay or collapse as a result of poor or no feasibility studies carried out to examine the factors responsible for the success if the reform is accepted. Consequently, this paper aims at identifying and assessing the factors influencing IPSAS acceptance in Cameroon.

The rest of the paper is structured to give a review of current and related literature of factors that affect government accounting reforms in a country, the methodology used in identifying and assessing the determinant factors of IPSAS acceptance in Cameroon, discussion of results, conclusion and recommendations.

\section{Literature Review}

In both the private and public sectors of a country where one party is paid by another to render a service, the two parties have different interests and asymmetric information. The agency theory explains this relationship between the principal and the agent in an organization. The owners of an organization constitute the principal while the managers are the agents (Donaldson and Davis, 1991; Guangdi and Fulwood, 2013). This relationship creates a principal-agent problem known as agency dilemma. This dilemma is the difficulty in motivating the agent to act in the best interests of the principal (Lucian and Jesse, 2004).

In the same vein, the citizenry in general and the tax payers in particular in a country are portrayed as the principal or owners of the public resources. The managers, users of the tax revenue, or the government are the agents who work for the interest of the principal. A government is managed by a group of elected persons who seek to maximize their personal interests instead of that of the citizenry. According to Guangdi and Fulwood (2013), undemocratic governments usually engage in pernicious tax policies and reckless spending that plunge the country into financial or sovereign debt crisis. However, the tax payers and the public have the right to seek accountability and transparency from the government that manages their resources.

The citizenry needs accurate, timely, reliable and complete financial reports in order to evaluate the government or the agent who has been given the power and authority to manage the scarce resources of the country for the benefit of the public. As a reward the government or agents are paid salaries, bonuses, and allowances. In some African countries the government agents especially those who were not given authority through the ballot box work largely for their own interest. However, for one to have control over their excesses Kathleen (1989) suggested that the principal invests in financial information systems. To do this the public sector accounting system or practice needs to be overhauled or reformed to produce accurate, reliable, complete and timely financial reports from which the citizenry carries out analyses to know the extent to which the agent worked for her interest.

The increasing interest in public sector accountability has also led to a management theory called New Public Management (NPM). This theory requires a change in management practices of the public sector towards more private sector practices, with accountability focusing on results instead of processes (Phetphrairin and Judy, 2011). According to its advocates the introduction of private sector methods and incentive structures into the public sector increases the efficiency of the public sector, thus making governments more financially accountable. 
Rhys and Steven, (2012) identified the critical force that drove the emergence of the NPM in the 1980s to be the conviction that large and monopolistic public bureaucracies were inherently unaccountable and inefficient. In developed countries such as Canada, Thailand, New Zealand, and Australia the major drive for the adoption of NPM was internal such as state crises and vested political interest. On the contrary, the NPM endorsement in developing countries is by external factors. Since the 1980s international agencies granting aid impose structural adjustment programs as pre-conditions for qualification. This was the main reason why some developing countries got involved in the NPM process. However, whether in developed or developing countries, NPM introduces a new obligation for efficiency and transparency into all elements of the public sector (Phetphrairin and Judy, 2011). This requires transitioning from traditional government accounting to accruals accounting.

In analysing the transition from traditional government accounting to accruals accounting, Lüder from 1980 to 1990 used the contingency model as a strong theoretical foundation in studying the government accounting systems in a series of countries including Canada, Germany, Denmark, France, Sweden, United Kingdom and the United States of America. The research examined the governmental accounting practices of these countries, and the identification of the environmental conditions that influenced accounting reforms. A contingency model was used to elucidate the reasons for which certain governments succeeded in implementing accounting innovation whilst others failed. Since then, the model has been widely cited and used as a standard for comparative international government accounting research (CIGAR) (Lüder, 1992).

The early CIGAR contingency model identified a set of contextual and behavioural variables that explained the result of the government accounting modernisation process. The contextual variables were categorised as stimuli, social environment of the government, characteristics of the political administrative system, and implementation barriers (Chan, 1996). Stimuli such as financial scandals of corruption and embezzlement common especially in the last two decades in Cameroon ignite the need for a more informative government accounting system, thus accounting innovation. Accounting innovation goes beyond conceptually procedural changes in the accounting system that provides comprehensive, reliable and meaningful financial information needed for proper financial accountability and sound financial management (Lüder, 1994).

As concerns the social environment of the government, structural variables such as political culture or patterns of political behaviour influence the basic attitudes of users and producers of information. In this regard, the more the political culture is opened and disposed towards public participation, the greater the information users' expectations of more comprehensive package of the government's financial management (Chan, 2003). In such circumstances the government is motivated to meet the expectations if it intends to secure votes in subsequent elections. It can then be deduced that where the government does not count on the strength of the ballot box to stay in power, as it is the situation in some African countries, the political culture is not opened for public participation.

Consequently, persuasive instigation to start a public sector accounting innovation is weak or absent. The implementation barriers as a contextual variable involve shortage of qualified or well-trained accountants in the public sector. This stifles the process of any government accounting transformation such as the acceptance of IPSAS. The first three of these contextual variables namely, stimuli, social environment of the government, characteristics of the political administrative system were surmised to positively influence the attitudes and behaviours of users and producers of government financial information (Lüder, 1994).

However, the attitudinal and behavioural variables were only added to these contextual variables while adapting the model in CIGAR. This implies that several new features were introduced by CIGAR in the second generation contingency models. The first feature is the definition of the roles of political actors and administrative actors. Political actors were seen as both consumers and producers of information, whereas administrative actors were identified as only producers of information. The second feature is that politics affects governmental accounting. For example a decision to accept IPSAS is political. Thirdly, the strengthening of financial functions such as creating positions of chief finance officers and the development of accounting standards setting boards affect the behaviour of the administrative actors positively.

Godfrey et al. (1996) in using the contingency model, introduced tribal identification and loyalty as factors that affect people's attitudes towards the public sector. Another variable identified to be influential on government accounting innovation is the international aid agencies. They demand and finance changes in the recipient country's system of accounting and financial reporting, as a condition for the award and renewal of financial assistance (Chan 1996). Donors and creditors tie the award and renewal of financial assistance to improvement in accounting and financial management systems. 
In another study the contingency model was used as a framework to describe the causes of accounting reform in the World Food Programme (Alesani et al., 2010). The findings were generalised into a revised contingency framework appropriate for intergovernmental organisations and public sectors. The research disclosed that staff qualification and preparedness affect an accounting reform, and transparency and accountability improve financial reporting.

The starting point or driving force of any accounting reform process is known as stimuli. They represent events which serve as a precondition for the accounting innovation decision. Stimuli generally result from the international convergence towards accounting harmonization, the international move to New Public Management (NPM), financial crises, and the resources dependency (Chan, 2005).

Lüder (1992) describes reformers as reform agents such as politicians, technicians implicated in the reform process, financial information users and the vigilant community. The immediate aftermath of the reformers' successful pressure for accounting reformation is a reform decision. This reform decision is described as the final stage of the Initiation Phase of any reform (Ouda, 2010). Reformers will criticize the government for its financial scandals involving corruption, embezzlement of funds, lack of accountability and transparency in financial management. A government can even become one of the reformers when it starts getting worried about its own performance and initiates ways to improve on its public financial management. For example, in an effort to combat corruption and embezzlement the Cameroon government has created structures such as the Anti-Corruption Commission (CONAC), the Audit Bench of the Supreme Court, and the Supreme State Audit.

\section{Methodology}

This study was carried out in the Ministry of Finance (MINFI) in Cameroon. MINFI is the nerve centre of accounting and financial management in the Cameroon public sector as defined by Decree No. 2008/365 of November 2008. It guides the budget preparation of all government Ministries before submission for approval by the parliament. In addition superintends budget implementation, and all the activities of the State treasuries such as revenue collection and disbursements. All Cameroon public sector Ministries, Regions and Local governments are linked to MINFI, for all their financial operations. It dictates the level of accountability and transparency in the management of public sector resources in Cameroon (Mukah, 2015).

A sample of 80 chiefs of center was drawn from a population of 249 MINFI centers drawn from the three administrative regions mentioned earlier which significantly represent the characteristics of the Cameroon public sector as a whole. The relevant population comprised directors or chiefs of Center, middle and top level full time Finance and Accounting staff of the Treasury, Taxation, and Custom departments of MINFI who have at least five years of work experience in the 249 MINFI centers in these three Regions. The views they expressed were institutional views rather than personal views. The sample was therefore purposive as it focused on criteria that guaranteed quality (Patton, 1990) following the researcher's knowledge of the research issue and the individual participants, Oliver and Jupp (2006).

A contingency framework of IPSAS acceptance in Cameroon presented in the appendix was designed. From this framework a contingency model of IPSAS acceptance in Cameroon was derived and presented as follows:

$$
\operatorname{AIPSAS}(\mathrm{Y})=f(\mathrm{STR}, \mathrm{IO}, \mathrm{MIS}, \mathrm{IC}, \mathrm{PS}, \mathrm{KA}, \mathrm{Q}, \text { Age, Sex })
$$

The econometric expression is as follows:

$$
Y_{i}^{*}=\alpha_{0}+\alpha_{1} S T R_{i}+\alpha_{2} I O_{i}+\alpha_{3} M I S_{i}+\alpha_{4} I C_{i}+\alpha_{5} P S_{i}+\alpha_{6} K A_{i}+\alpha_{7} Q_{i}+\alpha_{8} A g e_{i}+\alpha_{9} S E X_{i}+\varepsilon_{i}
$$

The observed ordered categorical variable model specification is:

$$
\frac{\operatorname{Pr}\left(Y_{i}>j\right)}{\operatorname{Pr}\left(Y_{i} \leq j\right)}=\exp \left(-u_{j}+\alpha_{0}+\alpha_{1} S T R_{i}+\alpha_{2} I O_{i}+\alpha_{3} M I S_{i}+\alpha_{4} I C_{i}+\alpha_{5} P S_{i}+\alpha_{6} K A_{i}+\alpha_{7} Q_{i}+\alpha_{8} A g e_{i}+\alpha_{9} \operatorname{Sex}_{i}\right)
$$

Where: $Y_{i}=\left\{\begin{array}{l}1 \text { if } Y_{i}^{*} \leq \mu_{1} \\ 2 \text { if } \mu_{1}<Y_{i}^{*} \leq \mu_{2} \\ 3 \text { if } \mu_{2}<Y_{i}^{*} \leq \mu_{3} \\ 4 \text { if } \mu_{3}<Y_{i}^{*} \leq \mu_{4} \\ 5 \text { if } Y_{i}^{*}>\mu_{5}\end{array}\right.$ 
$\alpha_{0}, \alpha_{1}, \alpha_{2}, \alpha_{3}, \alpha_{4}, \alpha_{5}, \alpha_{6}, \alpha_{7}, \alpha_{8}$, and $\alpha_{9}$ are the parameters to be estimated for all the variables in the regression equation. $\varepsilon i$ is the unpredicted, error or disturbance term with its assumed normalities. The a-priori expectation of the estimated parameters is that $\alpha_{1}, \alpha_{2}, \alpha_{3}, \alpha_{5}, \alpha_{6}, \alpha_{7}, \alpha_{9}$ are greater than 0 , which means that there exist a positive functional relationship between the adoption of IPSAS (AIPSAS) and the estimated parameters.

The coefficients in the model were estimated using, the Ordinary Least Square (OLS) estimations. With OLS the dependent variable requires ordered categories. In this model the order of categories is meaningful, but the distances between them may be arbitrary. OLS assumes that the distances between categories are the same for instance: the distance from "strongly agree" to "agree" equals to that from "agree" to "not decided" and "not decided" to "disagree" and "disagree" to "strongly disagree". In this regression model one could not be too sure that the distances between the orders of categories were equal so as to assure the credence of the OLS as a good estimation technique. Consequently, the ordered logistic estimation technique of the ordered logit estimation, which measures the change in the dependent variable per unit of the independent variable were also presented as an extra check of the robustness of the coefficients estimated by the OLS technique.

The original contingency model despite its several revisions, is exclusively useful for assessing the conduciveness of relevant environmental factors prevailing in a country to governmental accounting innovation (Ouda, 2010). It has shown remarkable robustness and adaptability in guiding many studies (Chan, 1996), and its adaptation to Cameroon has been very useful in this study. For these reasons, the variables were drawn from the Contingency framework of Public Sector Accounting Innovation by Lüder (1992) and Ouda (2010). Whereas these variables were used to analyse the transition from traditional government accounting to accrual accounting, this study used them in a contingency model to analyse the determinants of accrual IPSAS acceptance in Cameroon. A detail description of the variables gives a-priori expectation of the functional relationship that should exist between the dependent and the independent variables. The independent variables are the staff training and recruitment (STR), institutional organisation (IO), management information system (MIS) implementation cost (IC), political support (PS), knowledge and awareness (KA), qualification $(\mathrm{Q})$, age and sex.

Staff Training and Recruitment (STR) affect the basic attitudes and readiness of staff to contain public sector development of accounting. Qualifications of accountants which cover knowledge and experience of private sector accounting, gives reason to expect a more positive basic attitude to the introduction of a more informative accounting system. The United States and Canada have a large number of private sector accountants on their public sector accounting staff. Lüder (1992) associates this to the existence of formal legal requirements and also to the custom that lays emphasis on having professional accounting credentials such as Certified Public Accountants (CPA) in the United States and Certified Accountants (CA) in Canada to qualify for any high level government accounting and auditing positions.

However, in other countries such as Germany and the United Kingdom where the accounting staffs have not had any formal accounting education before, they are given on-the-job training. Consequently, specialist training or qualifications as accountants which are strongly oriented towards the private sector in terms of knowledge and experience as in Canada and the United States give reason to expect a more positive attitude towards an informative accounting system with the adoption of IPSAS. Staff Training and Recruitment (STR) are therefore expected to have a positive functional relationship with the acceptance of the IPSAS.

The success or failure of government accounting improvement also depends on the institutional organisation (IO) as the state structure, the culture, or the public function. Based on this contention Lüder (1992) sees the adoption of accounting innovation to be successful in the context of accounting professional domination than in bureaucrat monopolization. This suggests that the integration of accrual accounting (a crucial requirement in IPSAS) is more difficult in a bureaucratic structure than in a decentralised structure. Decentralisation being the dispersion or distribution of functions and powers specifically: the delegation of power from a central authority to regional and local authorities. This depends on the political will and top management and administrative support of the government.

In Cameroon, although Bill $\mathrm{N}^{\mathrm{0}} 762$ /PJL/AN on the Orientation of Decentralisation No 51/AN was promulgated into law on the $22^{\text {nd }}$ of July 2004 by president Biya, the process remains very slow. The government attributes this to lack of resources in the communes or councils. It would appear that unless there is a political will to effect a change in the management of public finances, the decentralisation process may just be a farce. However, Institutional Organisation (IO) has a positive functional relationship with the acceptance of the IPSAS.

Another variable that was tested to find out its influence on the adoption of IPSAS is Management Information System (MIS). Computerised information system is a key component of accounting, budgeting and financial management required to adopt accrual IPSAS accounting (Ouda, 2004). A sound MIS is a typically computer-based, and should be 
able to input data, process it into information, store both the data and information, and produces outputs such as financial, and management reports for decision making, planning, program implementation, and control. It is expected to have a positive functional relationship with the adoption of IPSAS.

Implementation Costs (IC) an accounting reform as IPSAS could be quite high. Costs are incurred to train the Accounts and Finance staff to be acquainted with the reform programme, costs of acquisition of both soft and hard wares, et cetera. Financial resources are required to carry out the adoption process and many countries have attributed their failure to adopt accrual accounting to lack of financial means (Ouda, 2004). For the cost of implementation to be determined, a budget of the adoption cost for the period, and how long the adoption process will last becomes crucial. Cameroon like most developing countries may seek international financial support in such a budget. However, the existence of IPSAS for free already cuts down significantly on the implementation cost. (Note 1) In any case, implementation cost is expected to have a negative functional relationship with adoption of IPSAS.

Political Support (PS), another independent variable is usually very crucial in creating changes in the public sector. The political support comes from both the executive and legislative bodies. In the case of New Zealand, the public sector accounting reform could not have been accomplished without the leadership of the Ministry of Finance and other key ministers involved in fiscal policy and public administration (Scott, 1996). The executive is the only official body that can take decisions to start and accomplish the accounting innovation process. On the other hand, the legislature apart of overseeing the activities of the executive, approves the budget and tax rates, and enacts laws among other things (Ouda, 2004). The introduction of IPSAS accrual accounting should be supported by adequate legal provisions. It is expected to have a positive functional relationship with the adopting of IPSAS.

Qualification, age and sex are socio-demographic variables which could play a crucial role in influencing the adoption of IPSAS. Age was captured by a four scale variable: 1 for 20 - 30 years; 2 for 31 - 40 years; 3 for 41 - 50 years and 4 for 51 years and above. Qualification was measured using the level of education and consequently it was also a scaled variable 1 for First School Leaving Certificate up to 6 for any other higher diploma in Accounting and Finance. In the estimation, sex was captured as a dummy variable. Sex equals 1 for males and 0 for females. Qualification is expected to have a positive relationship with IPSAS acceptance. On the other hand, age is expected to have a negative relationship with IPSAS acceptance (Meyer, 2008).

The ordered logistic method of estimation was used to establish the probability of the adoption behaviour of public sector institutions towards the IPSAS and the consequent quality of public sector accounting and financial reporting. It was necessary to test for heteroscedasticity, multicollinearity, and normality to validate the behaviour of the variables and their relationship in the logistic model. The test of homoscedasticity or heteroscedasticity assumes that the regression model has a constant variance and a zero mean for each error or disturbance term, $\varepsilon_{\mathrm{i}}$. Conditioned on the chosen values of the explanatory or independent variables, is some constant number equal to $\sigma^{2}$. This is the assumption of homoscedasticity. Symbolically, $\mathrm{E}\left(\mathrm{u}^{2}{ }_{\mathrm{i}}\right)=\sigma^{2}, \mathrm{i}=(1,2,3,4 \ldots \mathrm{n})$. The test statistics follows the student $\mathrm{t}$-statistic with a null hypothesis of homoscedasticity and an alternative of heteroscedasticity. If the null hypothesis in the status quo is rejected using the classical hypothesis testing rule, then there is the presence of heteroscedasticity and the model and its estimates would be consistent and efficient. In this study White's General Heteroscedasticity test was used as follows: $n \cdot R^{2}$ asy $\chi 2 \mathrm{df}$ (Gujarati, 2004).

In testing for multicollinearity the variance inflation factor (VIF) was used to determine whether or not multicollinearity was present among the variables of the model. OLS estimation technique assumes the variance of the error term to be constant. That means there is homoscedasticity and is given as: $\mathrm{V}(\varepsilon \mathrm{j})=\sigma^{2}$ for all $\mathrm{j}$. If the variances of the error terms are not constant, it implies they are heteroscedastic. A rule of thumb is that if the VIF is greater than 10, then multicollinearity is high. The VIF quantifies the severity of multicollinearity in an ordinary least squares regression analysis and is defined as:

$\mathrm{VIF}=\frac{1}{1-r_{i j}^{2}}, i \neq j$ and $r_{i j}^{2}$ is the correlation coefficient between any of the variables $\mathrm{X}_{1}, \mathrm{X}_{2}, \mathrm{X}_{3}, \mathrm{X}_{4}$, and others. The VIF shows how the variance of an estimator is inflated by the presence of multicollinearity. As $r_{i j}^{2}$ approaches 1 , the VIF approaches infinity. That is, as the extent of collinearity increases, the variance of an estimator increases and can become infinite (Gujarati, 2004).

\section{Data Analysis and Discussion of Results}

The summary statistics in Table 1 are the coded responses of the questionnaires so as to give an idea of the measure of central tendency: the mean, the standard deviation, the minimum and the maximum values of the qualitative variables 
used in the study. The maximum and minimum values indicate the range of the measure of the variables. For example, a minimum value of 1 and a maximum value of 5 in the case of the AIPSAS variable.

Table 1. Summary statistics of variables in the model

\begin{tabular}{lllll}
\hline Variable & Mean & Standard Deviation & Minimum & Maximum \\
\hline AIPSAS & 3.9000 & 0.988542 & 1 & 5 \\
STR & 20.5625 & 2.933196 & 12 & 25 \\
IO & 12.0750 & 2.231960 & 7 & 15 \\
MIS & 12.4750 & 1.330984 & 8 & 15 \\
IC & 10.1250 & 1.106654 & 8 & 14 \\
PS & 11.6000 & 0.805047 & 10 & 13 \\
KA & 3.3375 & 0.745344 & 2 & 5 \\
Q & 3.9375 & 1.487022 & 1 & 6 \\
Sex & 0.7750 & 0.420217 & 0 & 1 \\
Age & 2.6750 & 0.951681 & 1 & 4 \\
QPSAFR & 22.2250 & 2.116691 & 10 & 25 \\
A & 3.9750 & 1.006000 & 1 & 5 \\
T & 4.2625 & 0.568002 & 2 & 5 \\
\hline So & & & &
\end{tabular}

Source: Computed by the author

There were 80 observations. In general IO, STR, MIS, and IC, variables took values of positive integers between 1 and 25 based on the degrees of conformity of the responses to the questions in the questionnaire. However, the display of minimum values showed that for IO, STR, MIS, IC, PS and QPSAFR the minimum strength of responses given by the respondents were respectively $7,12,8,8,10$, and 10 . On the other hand, the maximum values indicated that the maximum strength of the responses by the respondents for the variables were respectively, 15, 25, 15, 14, 13, and 25.

The standard deviation is a shift from the central opinion in terms of quantifying the qualitative variables. The mean value of the qualitative variables indicated the bias of the responses to the questions for the variables in the models. For example the responses to whether the institutions would adopt the IPSAS are in general biased towards an acceptance region as the mean value is 3.9 which are closer to 5 . That is, there is a lot of perception that there should be an adoption of the International Public Sector Accounting Standards in Cameroon. The PS has a mean value of 11.6 which is biased towards the presence of political support for the adoption of the IPSAS. For the variables IO, STR, MIS, IC, and QPSAFR the mean values are generally higher than 10. Thus, the variables IO, STR, MIS and IC should contribute significantly to determine the adoption of IPSAS in Cameroon.

The regression results for the adoption of IPSAS are presented in Table 2. Column 2 presents the OLS results, while columns 3, 4 and 5 present different versions of the estimation of the ordered logit. Column 3 presents the results for the log odds, column 4 presents the results of the standardised ordered logit coefficients which are directly comparable to and interpreted as the OLS coefficients. The last column presents the odd ratios of the ordered logit estimation.

The result in column 2 for Staff Training and Recruitment (STR) shows that an increase in STR by one unit will result to an increase adoption of IPSAS by 0.1067 holding all other variables constant. This positive effect is consistent with the results obtained from Ordered Logit estimations, which also indicated that the likelihood of adopting IPSAS increases with STR. In terms of statistical significance the result is significant at the $1 \%$ level of significance and is in conformity with the a-priori expectation of the functional relationship that exist between STR and the adoption of IPSAS. This is supported by the work of Lüder (1992) which asserts that the training of administrative/accounting staff and the recruitment of qualified personnel for top fiscal positions affect their basic attitudes and readiness to contain public sector development of accounting. It further supports the work of Alesani et al. (2010) that disclosed among other things that Staff qualification and preparedness affect government accounting reform.

In terms of the current state of Institutional Organisation (IO), a unit increase in IO will result in an increase in the adoption of IPSAS by 0.1597 . This implies everything being equal the perception on IPSAS adoption will increase with institutional organisation that leads to decentralisation and an increase in autonomy of local governments. The statistical inference for IO implies that an increase in decentralisation and other Institutional Organisational factors 
such as legal framework, political will and top management support will greatly increase the probability to adopt the IPSAS in Cameroon.

Unfortunately, even though the law on decentralisation was promulgated on July 22, 2004 and a Ministry created to facilitate the process, decentralisation in Cameroon is still a farce. The delay in implementing this law by the government as the agent supports the agency theory reviewed in the literature. The elected officials maximize their own interest instead of that of the principal or the public. Unless the Cameroon government truly demonstrates a political will to decentralize the public service by allocating financial, material and man-power resources for the attainment, the process will remain dawdling. If the regions and councils are accorded autonomy, more accountability in the public sector management will be obtained (Tiron et al., 2007). In general, this finding on IO is consistent with the empirical works of Lüder (1994) and Ouda (2010). It is theoretically supported by the contingency model adopted in this study.

Management information system (MIS) is a major factor influencing the adoption of IPSAS. This is because computerisation facilitates the implementation of the accrual based IPSAS. It provides greater motivation of staff, efficiency in the use of resources, speedy gathering and automatic processing of data into information and making instant financial reports available to managers at all levels. Managers use this information for decision making, planning, program implementation, and control.

The results reveal that an increase in the level of MIS development will increase perception on the adoption of IPSAS. Precisely a unit increase in MIS will increase the adoption of IPSAS by 0.1063 , while the ordered logit results also show that an increase in MIS will increase the odds of adopting IPSAS. This implies that the level of MIS in the Public Sector has a high chance of adopting IPSAS. This corroborates with the a-priori expectation that establishes a positive functional relationship between the adoption of IPSAS and the MIS development. This coefficient is statistically significant at the $10 \%$ level of significance. 
Table 2. Presentation of the Logistic Regression Results for the Adoption of the IPSAS

\begin{tabular}{|c|c|c|c|c|}
\hline \multirow[t]{2}{*}{ Variable } & \multirow{2}{*}{$\begin{array}{l}\text { OLS } \\
\text { Coefficient } \\
\text { (t-statistics) }\end{array}$} & \multicolumn{3}{|c|}{ Ordered Logit Estimation } \\
\hline & & $\begin{array}{l}\text { Log odds } \\
\text { Coefficient } \\
\text { (z-statistics) }\end{array}$ & $\begin{array}{l}\text { Standardized } \\
\text { Coefficient } \\
\text { (Z-statistics) }\end{array}$ & $\begin{array}{l}\text { Odd ratio } \\
\text { Coefficient } \\
\text { (Z-statistics) }\end{array}$ \\
\hline STR & $\begin{array}{l}0.1067 * * * \\
(3.43)\end{array}$ & $\begin{array}{l}0.5895^{* * *} \\
(2.83)\end{array}$ & $\begin{array}{l}0.1125^{* * * *} \\
(2.83)\end{array}$ & $\begin{array}{l}1.8030 * * * \\
(2.83)\end{array}$ \\
\hline IO & $\begin{array}{l}0.1597 * * * \\
(4.65)\end{array}$ & $\begin{array}{l}0.8113^{* * *} \\
(4.75)\end{array}$ & $\begin{array}{l}0.1686^{* * *} \\
(4.75)\end{array}$ & $\begin{array}{l}2.2509 * * * \\
(4.75)\end{array}$ \\
\hline MIS & $\begin{array}{l}0.1063 * \\
(1.83)\end{array}$ & $\begin{array}{l}0.5739 * \\
(1.77)\end{array}$ & $\begin{array}{l}0.1192 * \\
(1.77)\end{array}$ & $\begin{array}{l}1.7751^{*} \\
(1.77)\end{array}$ \\
\hline IC & $\begin{array}{l}-0.0668 \\
(-0.88)\end{array}$ & $\begin{array}{l}-0.2786 \\
(-0.73)\end{array}$ & $\begin{array}{l}-0.0579 \\
(-0.73)\end{array}$ & $\begin{array}{l}0.7569 \\
(-0.73)\end{array}$ \\
\hline PS & $\begin{array}{l}-0.1483^{* *} \\
(-2.05)\end{array}$ & $\begin{array}{l}-0.8247 * * \\
(-2.23)\end{array}$ & $\begin{array}{l}-0.1713^{* *} \\
(-2.23)\end{array}$ & $\begin{array}{l}0.4384 * * \\
(-2.23)\end{array}$ \\
\hline KA & $\begin{array}{l}0.2157 * * * \\
(2.97)\end{array}$ & $\begin{array}{l}1.0506 * * \\
(2.54)\end{array}$ & $\begin{array}{l}0.2183^{* *} \\
(2.54)\end{array}$ & $\begin{array}{l}2.8594 * * \\
(2.54)\end{array}$ \\
\hline QUAL & $\begin{array}{l}0.0866^{* *} \\
(2.15)\end{array}$ & $\begin{array}{l}0.3744^{*} \\
(1.86)\end{array}$ & $\begin{array}{l}0.0778 * \\
(1.86)\end{array}$ & $\begin{array}{l}1.4541^{*} \\
(1.86)\end{array}$ \\
\hline AGE & $\begin{array}{l}-0.1855^{* * *} \\
(-3.16)\end{array}$ & $\begin{array}{l}-0.9003^{* * * *} \\
(-3.03)\end{array}$ & $\begin{array}{l}-0.1817 * * * \\
(-3.03)\end{array}$ & $\begin{array}{l}0.4064 * * * \\
(-3.03)\end{array}$ \\
\hline SEX & $\begin{array}{l}0.0442 \\
(0.28)\end{array}$ & $\begin{array}{l}0.2856 \\
(0.706)\end{array}$ & $\begin{array}{l}0.0593 \\
(0.706)\end{array}$ & $\begin{array}{l}1.3306 \\
(0.706)\end{array}$ \\
\hline CONSTANT & $\begin{array}{l}0.2502 \\
(0.14)\end{array}$ & & & \\
\hline Cut 1 & & 6.0794 & & \\
\hline Cut 2 & & 12.3792 & & \\
\hline Cut 3 & & 18.0817 & & \\
\hline Cut 4 & & 22.1638 & & \\
\hline $\begin{array}{l}\mathrm{F}(9,70) \text { or Wald } \\
\text { Chi-square }\end{array}$ & 43.74 & 65.83 & & \\
\hline $\begin{array}{l}\text { R-Square or Pseudo } \\
\text { R-Square }\end{array}$ & 0.7811 & 0.5380 & & \\
\hline
\end{tabular}

Source: Computed by the author

The number of observations is $80 . * * *, * * *$ represent $1 \%, 5 \%$ and $10 \%$ levels of significance. (The t-statistics and z-statistics were calculated using robust standard errors to control for potential heteroscedasticity

Implementation Cost (IC) has to do with the cost of implementing the accrual based IPSAS. The results show that a 1 unit increase in the implementation cost will result to a decrease in the chances of adopting IPSAS by 0.0668 . This result though statistically insignificant is consistent with the a-priori expectation. This is in consonance with Ouda (2004) reviewed which shows that many countries have attributed their failure to adopt accrual accounting to lack of financial means. 
The political support (PS) variable captures the political will to enforce various policies that can foster the adoption of different reforms in government accounting that will improve on accountability and transparency. The results show that an increase in the PS by one unit will decrease the odds of adopting IPSAS by 0.1483 , other variables held constant. The result is statistically significant at the 5\% level and is consistent with the results of the ordered logit estimations. Political support is a very important variable that can promote the development and use of innovative ICT related reforms such as the IPSAS. Most often this support is offered by creating conducive economic, social and political environment for installation and use of innovative ideas. However, the estimated coefficient for PS turns out to be negative, contrary to the a-priori expectation of this study. This finding ties with the assertion that the quality of the political institutions affects a country's ability to accept new technology.

For instance, Krusell and Rios-Rull (1996) present a model where incumbent innovators with enough political power block the introduction of new, competing technology. In Parente and Prescott (1994) monopoly rights increase barriers to technology adoption while Comin and Hobijn (2005) find empirical support for a similar model. In Cameroon the lobbyists or monopolists are those who benefit from the frail public sector accounting system.

Knowledge and awareness (KA) is very positively related to the likelihood of adopting IPSAS in all the estimation techniques. Precisely, the results show that an increase in KA by one unit will increase the level of adoption of IPSAS by 0.2157 . This is consistent with the a-priori expectation and statistically significant at the $1 \%$ level of significance. This result shows that once an individual has knowledge and awareness on the existence of an innovative program, the chances of adopting the program will increase. This result supports that obtained by Ouda (2010).

Qualification measures the level of education of the respondents. It is a variable which is highly acclaimed for innovative ideas and technological progress. The results show that there exists a positive relationship between qualification and the level of adopting IPSAS. By implication an increase in the level of qualification will increase both the level of perception and the likelihood of adopting IPSAS; the contrary is true. The results show further that an increase in the level of qualification by one will result to an increase in the likelihood of adoption of IPSAS by 8.66\%. This is statistically significant at the 5\% level of significance and is quite consistent with the theoretical expectation, and the functional relationship.

This result is supported by the study carried out by Alesani et al. (2010) which showed that qualification was quite instrumental in policies adopted to improve financial reporting. Knowledge is one of the important production factors. Thus, an efficient relationship exists between human capital and information communication technology (ICT) usage which is crucial for the adoption of IPSAS. This finding is quite consistent with studies that relate human capital development to adoption of innovative ICT related reforms such as the Mughal et al. (2011) findings that showed the importance of accumulation and development of human capital in productivity growth in the era of skill-biased technical change.

As it concerns the variable Age, an increase in the age group by one level decreases the likelihood of adopting IPSAS by 0.1855 . The result is statistically significant at $1 \%$ level of significance. role of age on innovative ideas and reform adoption related to ICT such as adoption of IPSAS has attracted a number of studies. Many of these studies show that there exist a negative relationship between age and technology related reforms adoption. Implication is that as individuals get older the likelihood of adopting innovative ideas falls. In this study the result confirms this. This is consistent with Meyer (2008) results which showed that firms with a higher share of younger employees are more likely to adopt new technologies while the older the workforce the less likely is the adoption of new technologies.

The last variable in the equation for the adoption of IPSAS is sex. The variable is positive which shows that males are more likely to adopt the IPSAS than females. The result precisely shows that a male is 0.0442 times more likely to adopt the IPSAS, even though statistically insignificant.

A look at the other columns of Table 2, confirms the results presented and discussed for the OLS, in terms of the signs of the coefficients. It would be observed that the magnitudes are not directly comparable because of the differences in estimation techniques. Notwithstanding that, the magnitudes of the results of column 4 that show the change in the dependent variable per unit of the independent variable or per standard deviation of the independent variable just as the OLS results are not very different. Hence, we can say the OLS results are consistent with the results of the ordered logit.

Other results presented in Table 2 are the F-Ratio for the OLS and the Likelihood Ratio (LR) statistical test for Ordered Logit Model (OLM) which tested the overall significance of the model. Both results based on their probability values show that the model is quite reliable and well fitted. This is supported by the R-Square of $78.11 \%$ in the OLS and a 
Pseudo R-Square of 0.5380 or $53.8 \%$ in the ordered logit model. These results indicate that more than $50 \%$ of the change in the adoption decision of IPSAS is explained by the variables included in the model.

To further verify the validity of the results, a test was conducted for the presence of multicollinearity since a multiple regression technique was adopted. The presence of this may invalidate the test statistics, leading to unreliable results. Table 3 presents the outcome of this test.

Table 3. Multicollinearity test results

\begin{tabular}{lll}
\hline Variable & VIF & 1/VIF \\
\hline STR & 2.35 & 0.4249 \\
IC & 2.24 & 0.4455 \\
IO & 1.65 & 0.6046 \\
MIS & 1.44 & 0.6953 \\
Q & 1.30 & 0.7686 \\
KA & 1.25 & 0.7990 \\
Age & 1.14 & 0.8771 \\
PS & 1.12 & 0.8950 \\
Sex & 1.08 & 0.9289 \\
Mean VIF & 1.51 & \\
\hline
\end{tabular}

Source: Computed by the author

The result from Table 3 clearly shows the absence of multicollinearity. Thus, there is no call for apprehension as far as this is concerned. It is worth mentioning that we also verified the presence of heteroscedasticity in the estimation was also verified.

\section{Conclusion and Recommendations}

In view of the findings generated in this study based on the results presented, the factors influencing the acceptance and implementation of IPSAS in Cameroon can be ranked in terms of magnitude of influence as follows: KA, IO, STR, MIS, Q, Sex, IC, PS and Age. Furthermore, the stimuli for the reformers are the financial scandals of corruption and embezzlement of public funds in Cameroon. However, the stimuli do not lead to a government accounting reform decision. Rather, they lead to knowledge and awareness about the need to reform the public sector accounting as reformers debate about the stimuli. It is only after or during the debate that a reform decision should take place.

The findings generated in the study lead to four key implications for policies. The first one is that knowledge and awareness be well imparted in the executive and legislative arms of the government, and the Cameroonian public on the need to have a sound public sector accounting system in general and accrual IPSAS based system in particular. Once these stakeholders are convinced that such a reform will safeguard the public treasury, ensure a smooth and transparent public sector financial management, the acceptance and implementation become largely facilitated.

Secondly, the Institutional Organisation especially in terms of decentralisation should be expedited with the government frankly demonstrating a political will by allocating financial, material and man-power resources to the local governments or councils.

Thirdly, the staff training and recruitment programme in MINFI be revised to increase technical empowerment of the staff. Formal legal requirements and custom that lay emphasis on having professional accounting credentials (Note 2) to hold any high level government accounting and auditing positions in the public sector be instituted.

Fourthly, the MIS should be improved with the incorporation of approved budgets in order to ensure informed financial decision making. For this to be effective, constant and stable electricity supply, and adequate and qualified MIS staff should be engaged.

Finally, even though IPSAS adoption adds value to a country's image by significantly improving transparency, accountability, decision making, financial management, quality and credibility of financial reports, transactions with financiers and simplifies communication with the general public; proper assessment of the factors influencing the acceptance and implementation of IPSAS remains pivotal to any successful government accounting reform. 


\section{References}

African Union and United Nations economic commission for Africa. (2015). Illicit Financial Flows; Report of the High Level Panel on Illicit Financial Flows from Africa commissioned by the AU/ECA Conference of Ministers of Finance, Planning and Economic Development. Retrieved 2015 from http://www.uneca.org/sites/default/files/PublicationFiles/iff_main_report_26feb_en.pdf

Alesani, D., Jensen, G., \& Steccolini, I. (2010). New information, new issues: the impact of IPSAS adoption on stakeholder identification of issues: an intergovernmental organisation study. Retrieved April 2014 from www.inderscience.com/info/inarticle.php?artid=48744

Biya, P. (2004). Bill $N^{o}$ 762/PJL/AN on the Orientation of Decentralisation No 51/AN. Retrieved 2014 from www.ccdhr.org,cameroon-laws

Chan, J. L. (1996). Research in governmental and non-profit accounting, Volume 9 (Research in Governmental \& Non-profit Accounting). Retrieved November 2012 from http://www.amazon.com / governmental-non-profit-accounting

Chan, J. L. (2003). Government Accounting: An Assessment of Theory, Purposes and Standards, Public Money and Management. Retrieved January, 2016 from http://ach.sagepub.com/content/17/3-4/287.refs

Chan, J. L. (2005). Government accounting reforms in developing countries: connecting MDG, PRS and IPSAS CIGAR. Retrieved October 2011 from http://www.feb.ugent.be/accoeco/Papers _ Cigar2011/49

Comin, D. \& Hobijn, B. (2005). Lobbying and Technology Diffusion, NBER Working Paper Series, No. 11022.

Donaldson, L. \& Davis, J. (1999). Agency Theory - Accounting practices. Retrieved August 2015 from http://www.ukessays.com /essays/finance/agencyory.php

Ehsan, R., Mehdi, P., Kamran, N. \& Mostafa, E. (2012). Government Accounting: An Assessment of Theory, Purposes and Standards. Interdisciplinary Journal of Contemporary Research in Business, 3(9).

Godfrey, A.D., Devlin, P.J. \& Merrouche, C. (1996). 'Governmental Accounting in Kenya, Tanzania, and Uganda'. Research in Governmental and Non-profit Accounting, 9, pp. 193-208.

Guangdi, C. \& Fulwood, C. (2013). An Agency Theory Approach to Sovereign Debt Crisis. The International Journal of Business and Finance Research, v. 7(5), 123-134.

Gujarati. (2004). Basic Econometrics. London: McGraw-Hill publishing company.

International Public Sector Accounting Standards Board. (2013). Benefits of IPSAS. Retrieved January 2016 from http://mddb.apec.org/Documents/2013/EC/PD2/13_ec_pd2_001a.pdf

Kathleen, M. E. (1989). Agency theory: An assessment and Review. The Academy of management Review, Vol. 14

Krusell, P. \& Rios-Rull, J. (1996). Vested Interests in a Positive Theory of Stagnation and Growth. Review of Economic Studies, 63(2). http://dx.doi.org/10.2307/2297854

Lucian, B. \& Jessie F. (2004). Pay without Performance: The Unfulfilled Promise of Executive Compensation. Cambridge: Harvard University Press.

Lüder, K. G. (1992). A contingency model of governmental accounting innovations in the political-administrative environment. Research in Governmental and Non-Profit Accounting, 7, 99-127.

Lüder, K. G. (1994). The Contingency model reconsidered: Experiences from Italy, Japan and Spain: Perspectives in performance measurement. Berne: Haupt.

Meyer, J. (2008). The Adoption of New Technologies and the Age Structure of the Workforce. ZEW Discussion Papers, No. 08-045. http://dx.doi.org/10.2139/ssrn.1210162

Mughal, Mazhar \& Barassou, D. (2011). Human Capital and the Adoption of Information and Communications Technologies: Evidence from Investment Climate Survey of Pakistan. Economics Discussion Papers, No 2011-21, Kiel Institute for the World Economy. http://dx.doi.org/10.2139/ssrn.1973464

Mukah, S. T. (2015). Effects of International Public Sector Accounting Standards Adoption on Public Sector Accounting and Financial Reporting in Cameroon. African Journal of Social Sciences, 6(4), 105-120.

Oliver, P. \& Jupp, V. (2006). Purposive sampling. The SAGE Dictionary of Social Research Methods. Sage, $244-245$. http://dx.doi.org/10.4135/9780857020116.n162 
Ouda, H.A. (2004). Basic requirements model for successful implementation of accrual accounting in the public sector. Public Fund Digest, 4(1), 78-99.

Ouda, H.A. (2010). A prescriptive model of the transition to accrual accounting in central government. International journal of governmental financial management. Retrieved October 2011 from www.scribd.com/doc/32869867

Parente, S. L. \& Prescott, E. C. (1994). Barriers to technology adoption and development. The Journal of Political Economy, 102(2). http://dx.doi.org/10.1086/261933

Patton, M. Q. (1990). Qualitative evaluation and research methods (2nd ed.). Newbury Park, CA: Sage Publications.

Phetphrairin, U. \& Judy, O. (2011). Accounting Change Model for the Public Sector: Adapting Luder's Model for Developing Countries. International Review of Business Research Papers, 7(1). January 2011, 364-380.

Rhys, A. \& Steven, W. (2012). New public management and citizens' perceptions of local service efficiency, responsiveness, equity and effectiveness, Retrieved January 2016 from http://www.cocops.eu/wp-content/uploads/2012/08/COCOPS_workingpaper_No7-.pdf

Scott, G. (1996). Government Reform in New Zealand, International Monetary Fund, Washington DC. http://dx.doi.org/10.5089/9781557755407.084

South Asian Federation of Accountants. (2006). A Study on accrual-based accounting for governments and public sector entities in SAARC countries. Retrieved November 2015from http://www.esafa.org/About/Study-Accrual_ accounting_in_saarc_governments_1.pdf

Tiron T., et al. (2007). Accrual accounting experience in the Romanian Public Higher Education Sector. Retrieved October 2011 from http://www.readingfanatic.com/index.jhtml?

\section{Notes}

Note 1. This notwithstanding, the Central African Economic and Monetary Community (CEMAC) countries instead of grabbing this free, tested and acclaimed package preferred to invent the will by adopting CEMAC directives in 2013.

Note 2. Such as Certified Public Accountants (CPA) in the United States and Certified Accountants (CA) in Canada.

Appendix - Contingency framework of IPSAS adoption in Cameroon

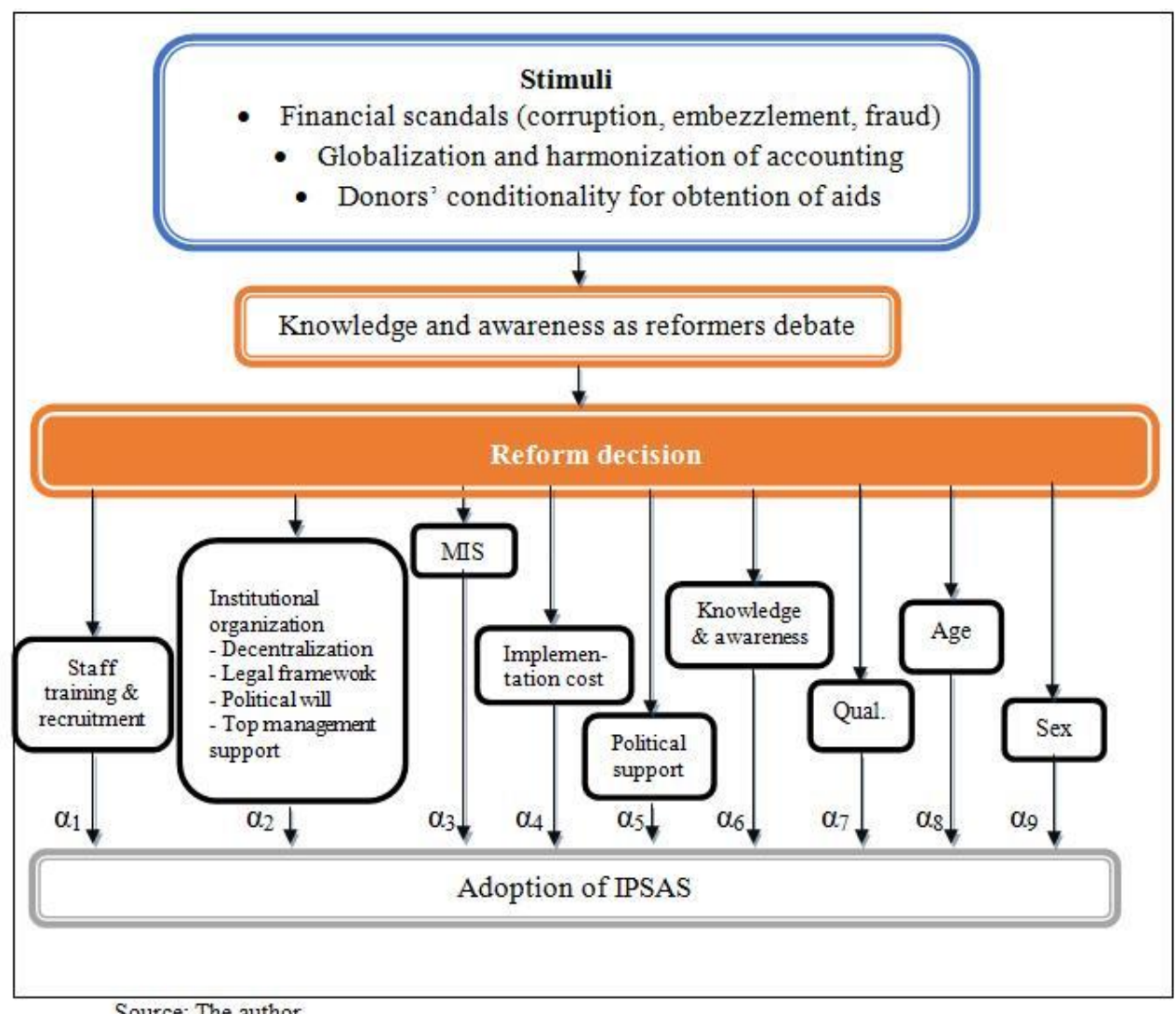

